\title{
New species of Trichuris (Nematoda: Trichuridae) parasitizing Heteromys salvini (Rodentia: Heteromyidae) from Costa Rica, with a key to Trichuris species described from Heteromyidae
}

\author{
Nova espécie de Trichuris (Nematoda: Trichuridae) de Heteromys salvini \\ (Rodentia: Heteromyidae) na Costa Rica, com uma chave para as espécies de \\ Trichuris descritas em Heteromyidae \\ Jorge Falcón-Ordaz; René Josué Monzalvo-López; Luis García-Prieto²* (1) \\ ${ }^{1}$ Laboratorio de Morfología Animal, Universidad Autónoma del Estado de Hidalgo, Mineral de la Reforma, Hidalgo, México \\ ${ }^{2}$ Instituto de Biología, Universidad Nacional Autónoma de México, México D.F., Mexico
}

How to cite: Falcón-Ordaz J, Monzalvo-López RJ, García-Prieto L. New species of Trichuris (Nematoda: Trichuridae) parasitizing Heteromys salvini (Rodentia: Heteromyidae) from Costa Rica, with a key to Trichuris species described from Heteromyidae. Braz J Vet Parasitol 2020; 29(2): e022019. https://doi.org/10.1590/S1984-29612020028

\begin{abstract}
Trichuris guanacastei n sp., a parasite isolated from the Salvin' spiny mouse Heteromys salvini, collected from the Guanacaste Conservation Area, Costa Rica, during February 1996 is described. The new species was compared morphologically with the 29 known species that parasitize rodents distributed in 12 families in North and South America; T. guanacastei n. sp. it is characterized by the following set of traits: presence of a spicular tube (measuring 0.72-0.99); thick proximal cloacal tube and a short distal cloacal tube with a total length of 0.72-1.36; eggs 0.03-0.05 long and a semi-protrusible vulva. The new species represents the first one described in the genus in Costa Rica and the fifth one described in the Americas that parasite Heteromyidae.
\end{abstract}

Keywords: Nematoda, new species, Rodentia, Guanacaste, Costa Rica.

\begin{abstract}
Resumo
O objetivo deste estudo foi descrever Trichuris guanacastei n. sp., um parasita isolado do rato espinhoso de Salvin, Heteromys salvini, coletado na Área de Conservação de Guanacaste, Costa Rica, durante fevereiro de 1996. A nova espécie foi comparada morfologicamente a 29 espécies conhecidas que parasitam roedores, distribuídas em 12 famílias na América do Norte e do Sul. T. guanacastei n. sp. é caracterizado pelo seguinte conjunto de características: presença de um tubo espicular (que mede 0.72-0.99); tubo proximal cloacal e um tubo distal cloacal com uma longitude total de 0.72-1.36; ovos de 0.03-0.05 de largura e uma vulva semi-protrusible. A nova espécie representa a primeira descrita do gênero na Costa Rica e a quinta descrita nas Américas que parasita Heteromyidae.
\end{abstract}

Palavras-chave: Nematoda, nova espécie, Rodentia, Guanacaste, Costa Rica. 


\section{Introduction}

Heteromyidae is a family of rodents distributed from southern Canada to northern Colombia and Venezuela; the family includes 50 species belonging to five genera (Chaetodipus, Dipodomys, Heteromys, Microdipodops and Perognathus) that inhabit different ecoregions (Alexander \& Riddle, 2005; Fernández et al., 2014; Hafner et al., 2007). In particular, Heteromys comprises 13 species, 7 of which [H. anomalus (Thompson), H. australis Thomas, H. desmarestianus Gray, H. gaumeri Allen, H. irroratus (Gray), H. pictus (Thomas) and H. salvini (Thomas)] have been studied from a parasitological perspective. In Costa Rica, this genus has been poorly studied; helminth species have only been reported in two $(H$. desmarestianus and $H$. salvini) of the four species distributed in the country (Falcón-Ordaz et al., 2019; Rodríguez-Herrera et al., 2014). In order to increase the knowledge of the nematode parasites of Heteromyidae rodents in this Central American country, we describe a new species of Trichuris collected from H. salvini. Twenty-nine species in this nematode genus have been recorded in American rodents belonging to the families Caviidae, Cricetidae, Ctenomyidae, Dasyproctidae, Echimyidae, Geomyidae, Heteromyidae, Myocastoridae, Octodontidae and Sciuridae (Eberhardt et al., 2019; Robles et al., 2018). The main morphological traits used to distinguish among them include the presence/ absence of a spicular tube (which contains the spicula), the length of the spicule, the shape of proximal cloacal tube (formed by the junction of the intestine and the ejaculatory tube) and distal cloacal tube (which in turn is originated by the junction of the proximal cloacal tube with the spicular tube) and vulvar morphology. Based on these features, we erected the new species and presented a taxonomic key for the species that parasitize American heteromyids.

\section{Materials and Methods}

Thirty-four individuals of $H$. salvini were collected by Sherman traps in February, 1996 from Área de Conservación Guanacaste, Costa Rica, and were examined for parasites. Nematodes were obtained from the caeca of the hosts and placed in $0.85 \%$ saline, fixed in glacial acetic acid and stored in $70 \%$ ethanol. Specimens were cleared for study with a solution of glycerol and 70\% ethanol (2:1). Drawings, micrographs and measurements were made with a Zeiss microscope equipped with a drawing tube and Axiocam ERc5s camera. Measurements are given in millimeters unless otherwise indicated. The range of measurements is presented at the beginning, followed by the mean, standard deviation and holotype or allotype measurements in parentheses. Specimens processed for scanning electron microscopy (SEM) were dehydrated through a graded series of ethanol, critical point dried with $\mathrm{CO}_{2}$ and sputter-coated with a mixture of gold-palladium; for SEM study were mounted on metal stubs with silver paste, and examined under a Hitachi Stereoscan S-2469 N at $15 \mathrm{kV}$ at Laboratorio Nacional de Biodiversidad (LANABIO), Instituto de Biología, Universidad Nacional Autónoma de México (IBUNAM), Mexico City, Mexico. Type material was deposited in the Colección Nacional de Helmintos (CNHE), IBUNAM, Mexico City, Mexico.

\section{Results}

Family Trichuridae (Ransom, 1911) Railliet, 1915

Genus Trichuris Roederer, 1761

Trichuris guanacastei n. sp. (17 males and 30 females)

General: Based on the holotype, allotype and paratypes. Cuticle with fine transverse striations. Anterior end of body long, narrow and sharp. Posterior end of body wide, diminishing towards the end (Figure 1A). Stichosome with a single row of stichocytes, and 1 pair of conspicuous cells at the esophagus-intestinal junction level. Nuclei of stichosome single with 1 nucleus per every 1 to 2 subdivisions; at the esophagus-intestinal junction level, they may present numerous nuclei within the stichosome (Figure 1B).

Male (Based on the holotype and 16 paratypes)

Total body length $13.31-22.75(18.03 \pm 6.67, n=2)(22.49)$. Ratio between anterior and posterior body length 1.24:1, $\mathrm{n}=1(1.10: 1)$ (Anterior part of body $7.90-12.63,10.27 \pm 3.34, \mathrm{n}=2)(12.50)$. Posterior part of body 8.32-10.11 $(9.27 \pm 0.63, n=12)(9.984)$. Width at middle of anterior part of body $0.104(0.104 \pm 0.0, n=2)(0.091)$. Width at level of esophagus-intestinal junction $0.15-0.26(0.21 \pm 0.04, n=13)(0.23)$. Width at middle of posterior part of body $0.23-0.36(0.30 \pm 0.045, n=12)(0.26)$. Total length of esophagus $7.9-12.63(10.27 \pm 3.34, n=2)(12.50)$, muscular portion $0.52-0.78(0.63 \pm 0.13, n=3)(0.66)$, stichosome portion 7.38-12.04 $(9.71 \pm 3.2, n=3)(11.83)$. 


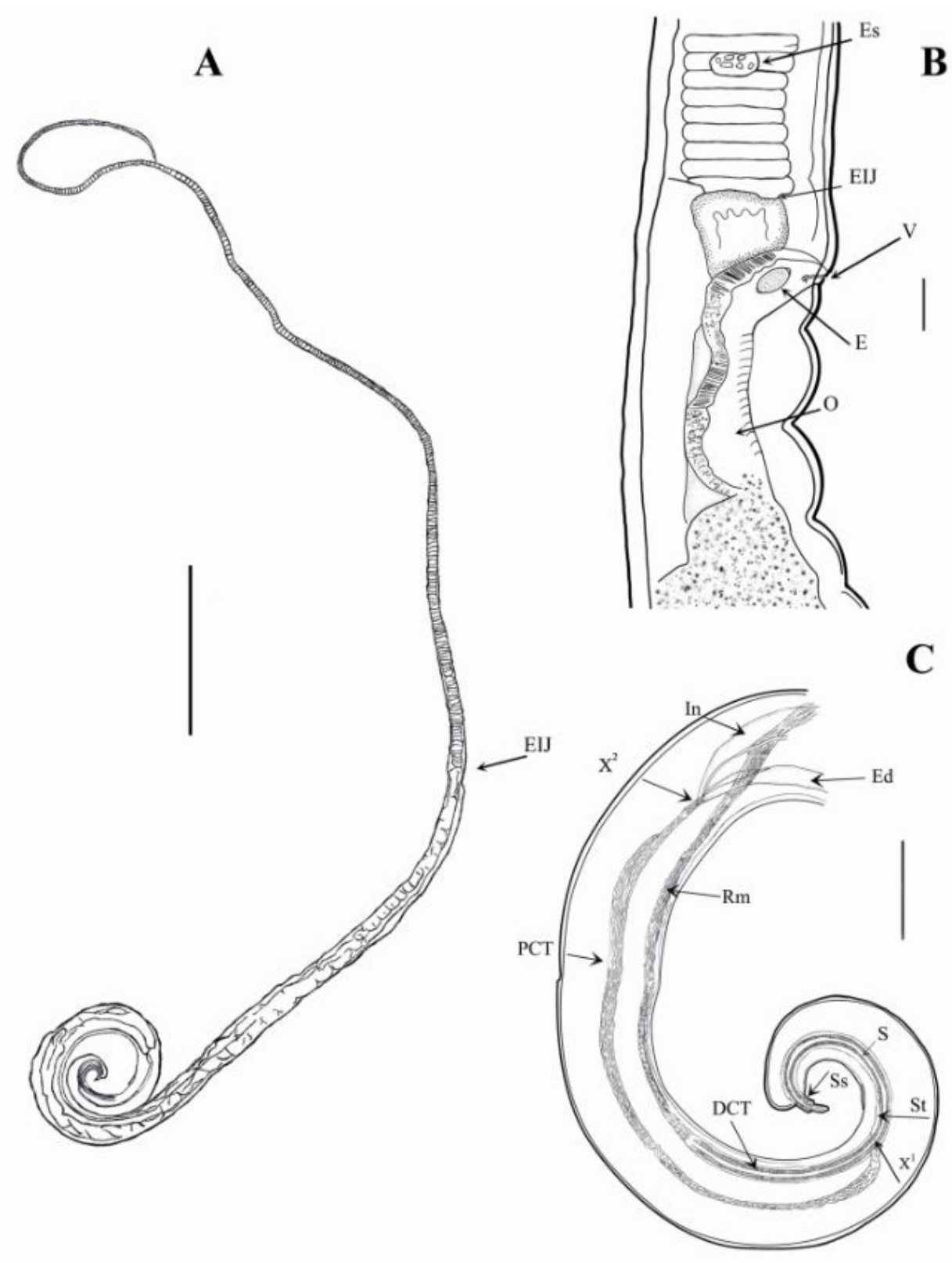

Figure 1. Trichuris guanacastei n. sp. (A) Male, total view, showing esophagus-intestinal junction (EIJ); (B) Female, showing stichosome with stichocytes (Es), esophagus-intestinal junction (EIJ), slightly protruding vulva (V), eggs (E) oval, flat with lemon form and bipolar plugs, and ovejector (O); (C) Posterior end of male, showing intestine (In), ejaculatory duct (Ed), junction of intestine and ejaculatory duct to form proximal cloacal tube (X2), retractor muscle (Rm), proximal cloacal tube (PCT), distal cloacal tube (DCT), junction of proximal cloacal tube and spicular tube (X1), spicular tube (St), spicule (S) and spicular sheath (Ss); Scale bar $200 \mu \mathrm{m}$.

The reproductive system (Figure $1 \mathrm{C})$ has a spicular tube with a length of $0.41-0.89(0.60 \pm 0.15, \mathrm{n}=11)$ (0.76). Spicule total length $0.72-0.99(0.86 \pm 0.09, n=6)(0.90)$. Width $0.009-0.02(0.01 \pm 0.004, n=6)(0.02)$ at tip, 0.005-0.01 (0.008 $\pm 0.002, \mathrm{n}=12)(0.006)$ at middle region, and 0.007-0.013 $(0.008 \pm 0.003, \mathrm{n}=13)(0.007)$ at base. Thicker proximal cloacal tube united laterally to the middle region of the shorter distal cloacal tube having a total length of $0.72-1.36(1.10 \pm 0.19, n=14)(1.15)$. Distance of junction of proximal cloacal tube to the beginning of distal cloacal tube $0.12-0.48(0.34 \pm 0.13, n=7)(0.46)$. Spicular sheath cylindric and densely spinose measuring $0.08-0.29(0.15 \pm 0.07, n=6)$ (0.08) (Figures 2A, 2B). Distal cloacal tube length 0.40-0.93 $(0.66 \pm 0.17, \mathrm{n}=14)(0.66)$. Width $0.01-0.03(0.02 \pm 0.005, \mathrm{n}=8)$ (0.02) at tip, $0.02-0.03(0.02 \pm 0.01, n=7)(0.02)$ at middle region and $0.02-0.04(0.03 \pm 0.008, n=8)(0.031)$ at base. Spicular retractor muscle 0.81-1.21 $(1.06 \pm 0.12, \mathrm{n}=8)(0.86)$. Testis $0.87-1.78(1.46 \pm 0.24, \mathrm{n}=13)(1.47)$ from the distal tip.

Ratio total body length/ posterior portion length 1.32-2.24 (1.78 $\pm 0.65, n=2)(1.78)$. Ratio posterior portion length/ anterior portion length $0.80(0.80 \pm 0, n=1)(0.79)$. Ratio total body length/ spicule length 

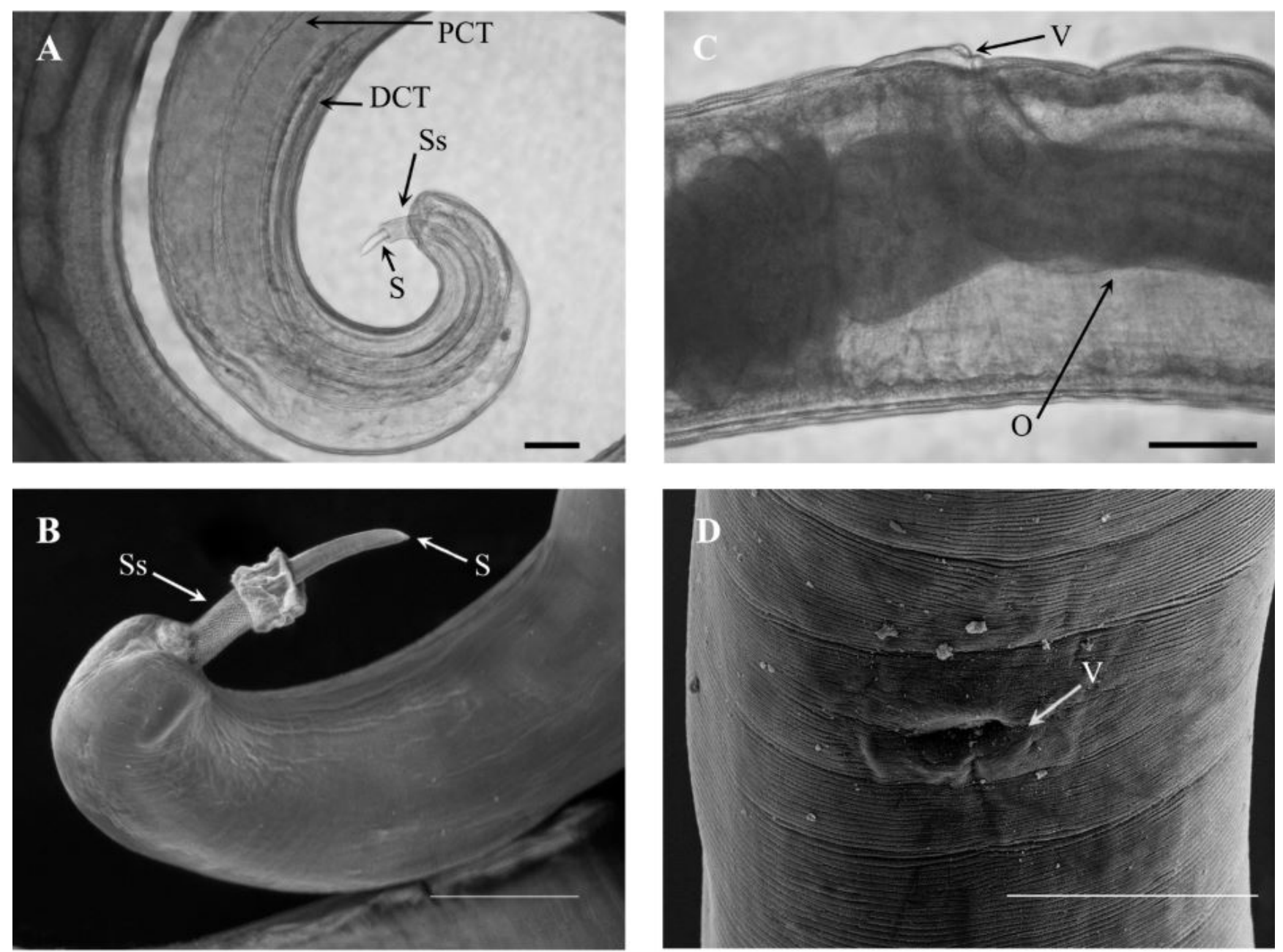

Figure 2. Trichuris guanacastein. sp. (A) Male, proximal cloacal tube (PCT), distal cloacal tube (DCT), spicular sheath (Ss), and spicule (S). Scale bar $5 \mu \mathrm{m}$; (B) Male, caudal end showing densely spinose spicular sheath (Ss) and spicule (S). Scale bar $100 \mu \mathrm{m}$. (C, D) Female, slightly protruding vulva (V) and ovejector (O). Scale bar $5 \mu \mathrm{m}$ and $100100 \mu \mathrm{m}$, respectively.

17.47-22.84 (20.16 $\pm 3.79, n=2)(24.78)$. Ratio posterior portion length/ spicule length 9.69-13.20 (10.85 $\pm 1.09, n=10)$

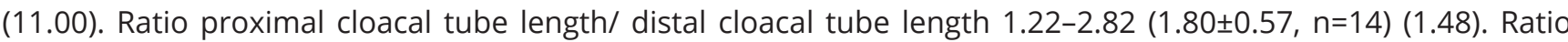
maximum posterior body width/ posterior portion length 0.02-0.03 $(0.03 \pm 0.004, \mathrm{n}=12)(0.02)$.

Female (Based on allotype, 29 paratypes)

Total body length 31.43-36.21 (33.82 $\pm 3.38, \mathrm{n}=2)(26.80)$. Ratio between anterior and posterior body length 0.85:1-1.03:1 (1.74 $\pm 2.01, n=2)(1.34: 1)$. Anterior part of body (filiform) $14.50-18.38(16.44 \pm 2.73, n=2)(15.39)$. Posterior part of body (fusiform) 9.28-21.26 (16.63 $\pm 3.54, n=13)(11.41)$.

Width at middle of anterior part of body $0.104(0.104 \pm 0.0, n=2)(0.09)$. Width at level of esophagus-intestinal junction $0.10-0.28(0.18 \pm 0.04, \mathrm{n}=22)(0.26)$. Width at middle of posterior part of body $0.26-0.57(0.41 \pm 0.08, \mathrm{n}=13)(0.52)$. Total length of esophagus $14.50-18.38(16.44 \pm 2.73, n=2)(15.39)$, muscular portion $0.60-0.853(0.72 \pm 0.17, n=2)(0.71)$, stichosome portion 13.90-17.53 $(15.71 \pm 2.56, \mathrm{n}=2)(14.67)$. Slightly protruding vulva, anterior lip mostly protruding than posterior (Figures 2C, 2D), located at 0.007-0.19 $(0.09 \pm 0.06, \mathrm{n}=14)(0.11)$ below the esophagus-intestinal junction and 9.29-19.25 (15.74 $\pm 3.81, \mathrm{n}=8)(11.46)$ from the distal tip. Ovejector 0.42-0.86 $(0.63 \pm 0.14, \mathrm{n}=13)(0.69)$ (Figure 2C). Eggs oval, flat with lemon form and bipolar plugs 15-22; 0.03-0.05 $(0.04 \pm 0.005) \times 0.020-0.028(0.025 \pm 0.001) \mathrm{mm}(\mathrm{n}$ $=25)$ (Figure 3A). Rectum length $0.07-0.41(0.25 \pm 0.10, n=14)(0.27)$. Anus subterminal, with a distance of 0.007-0.023 $(0.018 \pm 0.005, n=13)(0.0156)$ from de distal tip (Figure 3B, 3C). Ratio total body length/ posterior portion length $1.85-2.03(1.94 \pm 0.12, n=2)(2.34)$. Ratio posterior portion length/ anterior portion length $0.97-1.16(1.01 \pm 1.29, n=2)$ (1.01). Ratio maximum posterior body width/ posterior portion length $0.017-0.044(0.025 \pm 0.024, n=13)(0.044)$. 

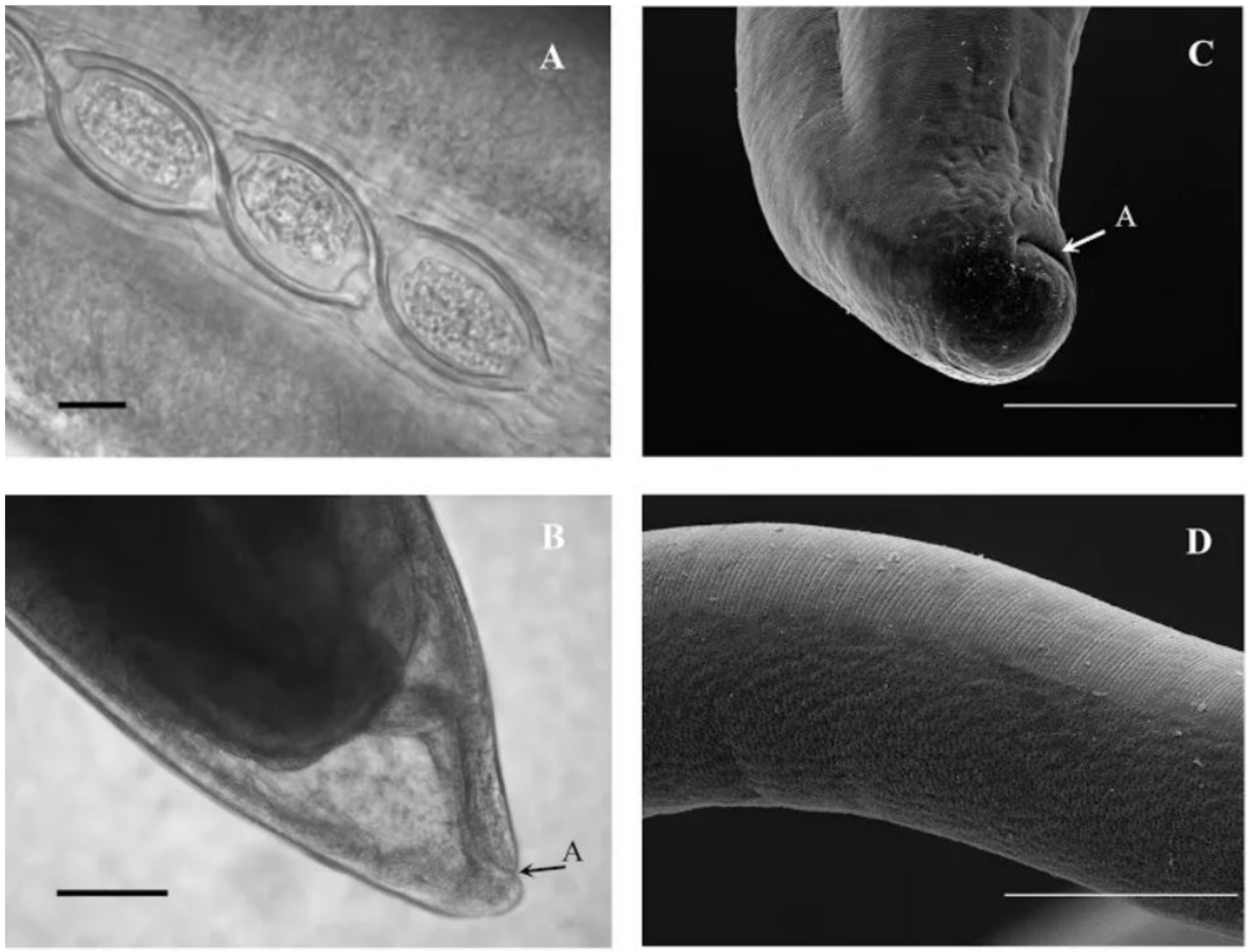

Figure 3. Trichuris guanacastei n. sp. (A) Female, eggs oval, flat with lemon form and bipolar plugs. Scale bar $1 \mu \mathrm{m}$; $(\mathrm{B}, \mathrm{C}) \mathrm{Caudal}$ end showing anus (A). Scale bar $5 \mu \mathrm{m}$ and $100 \mu \mathrm{m}$, respectively; (D) Bacillary glands with conspicuous pore in bacillary band. Scale bar $100 \mu \mathrm{m}$.

Bacillary band begins in the anterior region of the body, extending at its midpoint and fading gradually prior to the esophagus-intestinal junction. Bacillary band has cuticular inflations of different sizes and shapes bordering the band at the anterior end of the body; visible bacillary glands with conspicuous pore (Figure 3D).

Taxonomic summary

Type host: Heteromys salvini (Thomas, 1893) (Salvin’s spiny pocket mouse) (Rodentia: Heteromydae)

Site of infection: Cecum

Type locality: Área de Conservación Guanacaste, Costa Rica.

Prevalence and mean intensity: 58.82\% (20 infected rodents out of 34) and 2.35 individual per infected host.

Deposition of specimens: Holotype (CNHE 11250, male); Alotype (CNHE 11251, female); paratypes (CNHE 11252, 16 males, 29 females).

Etymology: the name of new species refers to Área de Conservación Guanacaste, Costa Rica, where the hosts were collected.

\section{Remarks}

The new species was compared with the 29 known species that parasitize rodents belonging to 12 families in North and South America: Trichuris guanacastei n. sp. differs from 12 of these 29 species (T. opaca Barker \& Noyes, 1915; T. bradleyi Babero, Cattan \& Cabello, 1975; T. chilensis Babero, Cattan \& Cabello, 1976; T. elatoris Pfaffenberger \& 
Best, 1989; T. robusti Babero \& Murúa, 1990; T. travassosi Correa-Gomes, Lanfredti \& De Souza, 1992; T. bursacaudata Suriano \& Navone, 1994; T. pampeana Suriano \& Navone, 1994; T. pardinasi Robles, Navone \& Notarnicola, 2006; T. navonae Robles, 2011; T. bainae Robles, Cutillas, Panei \& Callejón, 2014 and T. massoia Robles, Cutillas \& Callejón, 2018) by the presence of a spicular tube, while in the 12 referred species, the spicule lies entirely within the distal cloacal tube (Chandler, 1945; Tiner, 1950; Cameron \& Reesal, 1951; Read, 1956; Frandsen \& Grundmann, 1961; Todd \& Lepp, 1972; Babero et al., 1975, 1976; Barus et al., 1975; Babero \& Murúa, 1987, 1990; Pfaffenberger \& Best, 1989; Correa-Gomes et al., 1992; Suriano \& Navone, 1994; Robles et al., 2006, 2014, 2018; Robles, 2011; Torres et al., 2011; Panti-May \& Robles, 2016, Eberhardt et al., 2019).

For 2 of the 17 remaining species, T. gracilis (Rudolphi, 1819) and T. dolichotis Morini, Boero \& Rodriguez, 1955, the males are unknown. Despite this, these species can be differentiated of $T$. guanacastei $n$. sp., because the females of both species present a non-protrusive vulva; in the new species, the vulva is semi-protrusive. Additionally, the total body size and anterior end of the body of $T$. gracilis (38.5-39.6 and 21.55-27.44 mm, respectively) are larger than those in T. guanacastei (31.43-36.21 and 14.50-18.38 mm, respectively), and egg size of the new species (0.03-0.05) is smaller than in that of T. dolichotis (0.075) (Robles, 2011; Panti-May \& Robles, 2016). Fifteen species in the genus have a spicular tube similar to that of the new species: T. muris (Schrank, 1788) Hall, 1916, T. fossor Hall, 1916; T. myocastoris Enigk, 1933, T. citelli Chandler, 1945, T. perognathi Chandler, 1945, T. neotomae Chandler, 1945, T. peromysci Chandler, 1946, T. madisonensis Tiner, 1950, T. stansburyi Frandsen \& Grundmann, 1961, T. fulvi Babero \& Murua, 1987, T. dipodomis Pffafenberger \& Best, 1989, T. laevitestis Suriano \& Navone, 1994, T. silviae Panti-May \& Robles, 2016, T. thrichomysi Torres, Nascimento, Menezes, García, Santos, Maldonado, Miranda, Lanfredi \& Souza, 2011 and T. cutillasae Eberhardt, Robles, Monje, Beldomenico \& Callejón, 2019. Nonetheless, 9 of these species have a longer spicular length than that of Trichuris guanacastei n. sp. (0.72-0.99): T. citelli (1.15-6.8), T. cutillasae (2.70-2.94), T. dipodomis (1.15-1.23), T. fulvi (1.21-1.33), T. laevitestis (3.47-3.71), T. myocastoris (2.96-4.5), T. neotomae (1.3-2.1), T. silviae (1.3-1.4) and T. thrichomysi (1.86-2.78). In addition, the new species can be differentiated from T. citelli, T. cutillasae, T. fulvi and T. myocastoris by the total body length in males, which is 13.31-22.75 in the Costa Rican species and varies between 23.5 and 56.52 in the other species. Furthermore, the distal cloacal tube length in $T$. guanacastei n. sp. (0.40-0.93) is smaller than those in T. citelli (1.10-1.30), T. cutillasae (1.14-2.2) and T. myocastoris (1.26-2.63). On the other hand, the eggs of T. fulvi, T. laevitestis, T. neotomae, T. silviae and T. thrichomysi are smaller than those of $T$. guanacastei $n$. sp. (0.03-0.05 in the new species vs 0.06 to 0.09 in the other 5 species). An additional feature that allows the differentiation of $T$. fulvi, T. laevitestis and $T$. silviae and the new species is the presence of a non-protrusive vulva in these 3 species and a semi-protrusive vulva in T. guanacastei. Similarly, the anterior part of the body of $T$. neotomae males' measures 14.0 to 17.0 while in $T$. guanacastei $\mathrm{n}$. sp. this region only measures 7.09-12.63 in length. Another useful feature to distinguish T. guanacastei from $T$. thrichomysi is the length of the spicular tube (0.41-0.89 vs. 1.73-2.02, respectively), and the distance of the testis makes it possible to differentiate the new species from $T$. dipodomis, since this is greater in the Costa Rican specimens $(0.87-1.78)$ than in T. dipodomis (0.43-0.58).

Other 3 species with spicular tube ( $T$. fossor, T. madisonensis and $T$. peromysci) can be differentiated from Trichuris guanacastei n. sp. because their vulva is not protrusive, while in the new species, it is semi-protrusive; further, the length of eggs of these 3 species range from 0.069 to 0.092 vs 0.03-0.05 in T. guanacastei $\mathrm{n}$. sp.

The length of the proximal cloacal tube of two of the three remaining species with a spicular tube as T. guanacastei, i.e., $T$. muris (0.80-2.18, average 1.38) and T. stansburyi (1.74), differentiates them because their proximal cloacal tube is greater than that of the new species $(0.72-1.36$, average 1.10). Furthermore, the width of the spicule base of the Costa Rican species (0.007-0.013) is smaller than those reported for T. stansburyi (0.027-0.052) and T. muris (0.020-0.040). In the same way, the length of the eggs of the 3 species (T. muris: 0.062-0.068; T. stansburyi: 0.051-0.063 and T. guanacastei: 0.03-0.05) makes their distinction possible (Feliu et al., 2000; Frandsen \& Grundmann, 1961).

Finally, the total length of males (13.31-22.7) and females (31.43-36.21) of T. guanacastei $n$. sp. is smaller than the total length of males (25.0-30.0) and females (46.0-47.0) of $T$. perognathi, the final species of the genus with a spicular tube; moreover, the eggs size of the new species (0.03-0.05) and the cloacal tube length (0.72-1.36) clearly distinguish it from $T$. perognathi, in which these structures measure $0.065-0.067$ and $2.00 \mathrm{~mm}$, respectively.

\section{Discussion}

Trichuris guanacastei n. sp. is the first species of Trichuris described in Costa Rica and the fifth species described in the Americas that parasitizes Heteromyidae (Chandler, 1945; Read, 1956; Pfaffenberger \& Best, 1989; Panti-May \& Robles, 2016). The new species was compared with 29 known species of Trichuris that infect rodents in the 
Americas and separated from these species based on a combination of various morphological characteristics in both males and females, mainly the presence of a spicular tube, the spicule size, vulvar morphology, and the length of the eggs. However, the identification of the Costa Rican specimens was difficult because some of their morphometric characteristics overlap, particularly with species that parasitize host included in the same family (T. silviae, T. perognathi, T. elatoris and T. dipodomis, see Robles, 2008). In addition, as Panti-May \& Robles (2016) noted, the descriptions of some species are incomplete (e.g., T. dipodomis, T. perognathi, T. stransburyi, T. madisonensis and T. fossor), and the nomenclature of several traits should be clarified, especially those related to vulvar morphology as well as the spicular sheath. Authors such as Panti-May \& Robles (2016) and Hasegawa \& Dewi (2017) have analyzed the taxonomic value that features such as the presence/absence of a cephalic stylet, the characteristics of the bacillary band and accompanying structures, and the number and shape of nuclei in the stichocytes could have for the identification of Trichuris species. Further, DNA sequencing analysis of Trichuris species will be a key element for their differentiation in the future.

Key to the species of Trichuris parasites of Heteromyidae rodents

1.- Spicular tube absent T. elatoris; Dipodomys elatoris Merriam, 1894

Spicular tube present .2

2.- Projections of spicular sheath acute 3

Projections of spicular sheath saccular T. dipodomis; Dipodomys ordii Woodhouse, 1853

3.- Length of spicule $<1.00 \mathrm{~mm}$

Length of spicule $1.30 \mathrm{~mm}$ to $1.50 \mathrm{~mm}$

T. silviae; Heteromys gaumeri Allen and Chapman, 1897

4.- Length of cloacal tube $<1.40 \mathrm{~mm}$. Trichuris guanacastei n. sp. H. salvini (Thomas, 1893)

Length of cloacal tube $2.00 \mathrm{~mm}$ T. perognathi; Chaetodipus californicus (Merriam, 1889)

\section{Acknowledgments}

We thank Daniel R. Brooks for providing specimens for this study. Berenit Mendoza-Garfias (Scanning Electron Microscopy, Instituto de Biología, UNAM) for assisting in processing samples for SEM. Georgina Ortega-Leite provided some important literature.

\section{References}

Alexander LF, Riddle BR. Phylogenetics of the new world rodent Family Heteromyidae. J Mammal 2005; 86(2): 366-379. http:// dx.doi.org/10.1644/BER-120.1.

Babero BB, Cattan PE, Cabello C. Trichuris bradleyi sp. n., a whipworm from Octodon degus in Chile. J Parasitol 1975; 61(6): 10611063. http://dx.doi.org/10.2307/3279376. PMid:1195067.

Babero BB, Cattan PE, Cabello CA. A new species of whipworm from the rodent Akodon longipilis in Chile. Trans Am Microsc Soc 1976; 95(2): 232-235. http://dx.doi.org/10.2307/3225071. PMid:1274050.

Babero BB, Murua RB. A new species of whipworm from a South American hystricomorph rodent. Mem Inst Oswaldo Cruz 1990; 85(2): 211-213. http://dx.doi.org/10.1590/S0074-02761990000200012.

Babero BB, Murua RB. The helminth fauna of Chile. X. A new species of whipworm from a Chilean rodent. Trans Am Microsc Soc 1987; 106(2): 190-193. http://dx.doi.org/10.2307/3226320.

Barus V, Madjumdar G, Mikailov TK. Morphology and taxonomy of Trichocephalus myocastoris (Enigk, 1933). Folia Parasitol (Praha) 1975; 22(3): 207-213. PMid:1193482.

Cameron TWM, Reesal MR. Studies on the endoparasitic fauna of Trinidad mammals: VII. parasites of hystricomorph rodents. Can J Zool 1951; 29(4): 276-289. http://dx.doi.org/10.1139/z51-025.

Chandler AC. Trichuris species from California rodents. J Parasito/ 1945; 31(4): 284-287. http://dx.doi.org/10.2307/3273006.

Correa-Gomes D, Lanfredti RM, Pinto RM, Souza W. Description of Trichuris travassosi n. sp. (Nematoda: Trichurinae) from a Brazilian rodent, by light and scanning electron microscopy. Mem Inst Oswaldo Cruz 1992; 87(Suppl 1): 1-10. http://dx.doi. org/10.1590/S0074-02761992000500004. PMid:1343784. 
Eberhardt AT, Robles MR, Monje LD, Beldomenico PM, Callejón R. A new Trichuris species (Nematoda: Trichuridae) from capybaras: Morphological-molecular characterizacion and phylogenetic relationships. Acta Trop 2019; 190: 244-252. http://dx.doi. org/10.1016/j.actatropica.2018.11.029. PMid:30500368.

Falcón-Ordaz J, García-Prieto L, Cordero-Lezama AY. Nematode Parasites of Rodents (Sigmodontinae) and Update of Those Recorded in Other Wild Mammals from Costa Rica. Comp Parasito/ 2019; 86(1): 41-52. http://dx.doi.org/10.1654/1525-2647-86.1.41.

Feliu C, Spakulová M, Casanova JC, Renaud F, Morand S, Hugot JP, et al. Genetic and morphological heterogeneity in small rodent whipworms in southwestern Rurope: characterization of Trichuris muris and description of Trichuris arvicolae n. sp. (Nematoda: Trichuridae). J Parasitol 2000; 86(3): 442-449. http://dx.doi.org/10.1645/0022-3395(2000)086[0442:GAMHIS]2.0. CO;2. PMid:10864238.

Fernández JA, Hafner MS, Hafner DJ, Cervantes FA. Conservation status of rodents of the families Geomyidae and Heteromyidae of Mexico. Rev Mex Biodivers 2014; 85(2): 576-588. http://dx.doi.org/10.7550/rmb.36710.

Frandsen JC, Grundmann AW. Trichuris stansburyi and Gongylonema mysciphilia, two new species of nematodes from the deer mouse in Utah. Proc Helminthol Soc Wash 1961; 28(1): 91-94.

Hafner JC, Light JE, Hafner DJ, Hafner MS, Reddington E, Rogers DS, et al. Basal clades and molecular systematics of heteromyid rodents. J Mammal 2007; 88(5): 1129-1145. http://dx.doi.org/10.1644/06-MAMM-A-413R1.1.

Hasegawa H, Dewi K. Two new species of Trichuris (Nematoda: Trichuridae) collected from endemic murines of Indonesia. Zootaxa 2017; 4254(1): 127-135. http://dx.doi.org/10.11646/zootaxa.4254.1.9. PMid:28609987.

Panti-May JA, Robles MR. A new species of Trichuris Roederer, 1761 (Nematoda: Trichuridae) from Heteromys gaumeri Allen \& Chapman (Rodentia: Heteromyidae) in Yucatan, Mexico. Syst Parasito/ 2016; 93(7): 721-730. http://dx.doi.org/10.1007/s11230016-9656-6. PMid:27522370.

Pfaffenberger GS, Best T. Trichuris elatoris sp. n. (Nematoda: Trichuridae) from the Texas kangoroo rat (Dipodomys elator). Proc Helminthol Soc Wash 1989; 56(1): 76-81.

Read CP. Trichuris dipodomis n. sp., from Ord's kangaroo rat. Proc Helminthol Soc Wash 1956; 23(2): 489-496.

Robles MR, Cutillas C, Callejón R. Morphological-molecular characterizacion and phylogenetic relationships of a new Trichuris species (Nematoda: Trichuridae) parasitic on Holochilus chacarius (Cricetidae: Sigmodontinae) from the Chaco ecoregion (Argentina). Infect Genet Evol 2018; 58: 66-76. http://dx.doi.org/10.1016/j.meegid.2017.11.029. PMid:29241714.

Robles MR, Cutillas C, Panei CJ, Callejón R. Morphological and molecular characterization of a new Trichuris species (NematodaTrichuridae), and phylogenetic relationships of Trichuris species of cricetid rodents from Argentina. PLoS One 2014; 9(11): e112069. http://dx.doi.org/10.1371/journal.pone.0112069. PMid:25393618.

Robles MR, Navone GT, Notarnicola J. A new species of Trichuris (Nematoda: Trichuridae) from Phyllotini rodents in Argentina. J Parasitol 2006; 92(1): 100-104. http://dx.doi.org/10.1645/GE-GE-552R.1. PMid:16629323.

Robles MR. Nematodes Oxyuridae, Trichuridae y Capillariidae en roedores Akodontini (Cricetidae: Sigmodontinae) de la cuenca del Plata, Argentina: su importancia en la interpretación de las relaciones parásito-hospedador-ambiente [dissertation]. La Plata: Facultad de Ciencias Naturales y Museo, Universidad Nacional de la Plata; 2008.

Robles MR. New Species of Trichuris (Nematoda: Trichuridae) from Akodon montensis Thomas, 1913, of the Paranaense Forest in Argentina. J Parasitol 2011; 97(2): 319-327. http://dx.doi.org/10.1645/GE-2434.1. PMid:21506781.

Rodríguez-Herrera B, Ramírez-Fernández JD, Villalobos-Chaves D, Sánchez R. Actualización de la lista de mamíferos vivientes de Costa Rica. Mastozool Neotrop 2014; 21(2): 275-289.

Suriano DM, Navone GT. Three new species the genus Trichuris Roederer, 1761 (Nematoda- Trichuridae) from Cricetid and Octodontidae rodents in Argentina. Res Rev Parasitol 1994; 54(1): 39-46.

Tiner JD. Two new species of Trichuris from North America, with redescriptions of Trichuris opaca and Trichuris leporis (Nematoda: aphasmidia). J Parasitol 1950; 36(4): 350-354. http://dx.doi.org/10.2307/3273470. PMid:15437235.

Todd KS, Lepp DL. Redescription of Trichuris fossor Hall, 1916 (Nematoda: Trichuridae) from the northern pocket gopher, Thomomys talpoides. Proc Helminthol Soc Wash 1972; 39(2): 203-205.

Torres EJL, Nascimento APF, Menezes AO, Garcia J, Santos MAJ, Maldonado A Jr, et al. A new species of Trichuris from Trichomys apereoides (Rodentia: Echimyidae) in Brazil: Morphological and histological studies. Vet Parasitol 2011; 176(2-3): 226-235. http:// dx.doi.org/10.1016/j.vetpar.2010.10.053. PMid:21109353. 